\title{
Refractory multisystem sarcoidosis involving pelvic bone responding to infliximab
}

\author{
Uma Karjigi*, Anupam Paul \\ From Northern and Yorkshire Deaneries Annual Rheumatology Conference \\ York, UK. 26 September 2012
}

\begin{abstract}
Background
Chronic progressive multisystem granulomatous disease is seen in $10-30 \%$ of patients with sarcoidosis and can result in end organ damage [1]. Corticosteroids are the mainstay of treatment with the addition of cytotoxic agents in severe cases. Some patients are refractory to such treatment and therefore management is a challenge. There is currently limited evidence for biological agents such as infliximab, a monoclonal anti-tumor necrosis factor- $\alpha$ antibody in the treatment of multisystem sarcoidosis. Aim of this case report is to disseminate knowledge concerning successful treatment of multisystem sarcoidosis involving pelvis with the use of TNF- $\alpha$ blockers in refractory cases.
\end{abstract}

\section{Case presentation}

$33 \mathrm{yr}$ old lady referred to Rheumatology with arthralgia, myalgia, malaise, headaches, facial swelling, nausea, vomiting, ear and neck pain and tingling in her fingers. Her past medical history revealed uveitis. Subsequently she developed Right facial palsy and noted to have bilateral parotid enlargement. Chest X-ray and CT chest confirmed extensive mediastinal and bilateral hilar lymphadenopathy. Serum ACE levels were elevated and lymphnode biopsy confirmed Sarcoidosis.

She was started on oral prednisolone $40 \mathrm{mg}$ daily with good response. However she developed erythema nodosum, relapse of uveitis and repeated episodes of hypercalcemia needing hospital admission on trying to reduce the dose of steroids. She complained of pain in hip joints. MRI Pelvis showed multiple bony lesions and bone biopsy confirmed bony involvement of sarcoidosis.

\section{Treatment}

Intavenous zolendronic acid helped with bone pain and hypercalcemia. Commenced on azathioprine however

\footnotetext{
* Correspondence: u.karjigi@nhs.net

James Cook University Hospitals NHS Trust, UK
}

unable to tolerate because of headaches. Continued to have active disease and started on infliximab and methotrexate. She improved on this combination treatment and managed to reduce steroids gradually. She is on this treatment for a year and the condition is well controlled.

\section{Discussion}

Granulomatous bone involvement has an overall incidence of 1-13\%. The small bones of hands and feet are the most common localizations, while skull, knee, rib, pelvic and sternal localizations are rarely reported [2]. The diagnosis of the sarcoid is based on the clinical presentation, radiological manifestations and histopathological assay. Even though radiographic findings are characteristic, could be challenging to distinguish from bony metastasis. On literature review there are reported case of vertebral sarcoidosis treated with anti TNF

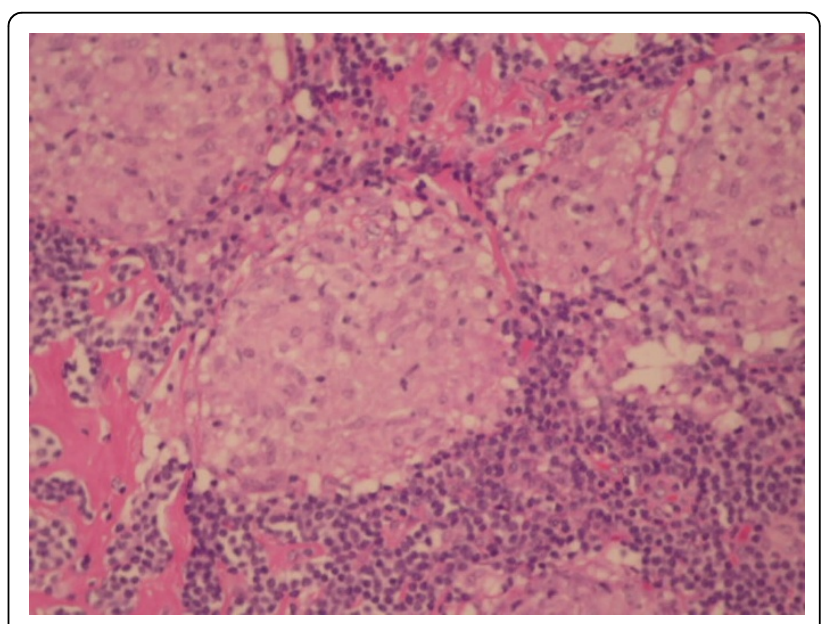

Figure 1 Cervical node biopsy showing Granulomas with little lymphoid tissue

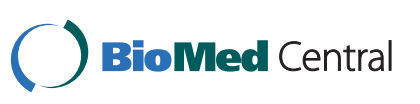

() 2013 Karjigi and Paul; licensee BioMed Central Ltd. This is an Open Access article distributed under the terms of the Creative Commons Attribution License (http://creativecommons.org/licenses/by/2.0), which permits unrestricted use, distribution, and reproduction in any medium, provided the original work is properly cited. 


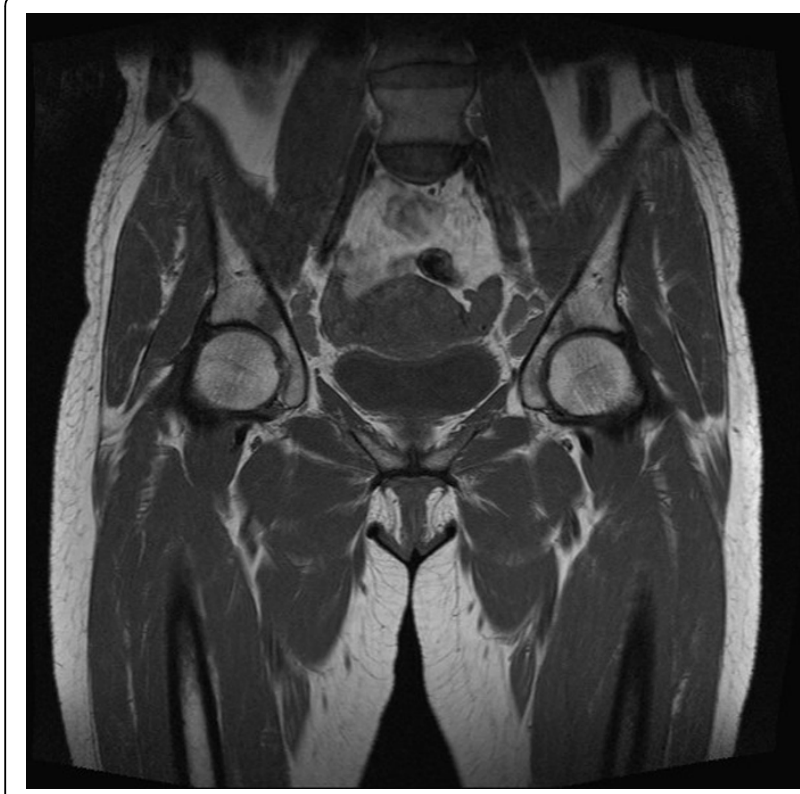

Figure $2 \mathrm{MRI}$ pelvis showing lesions over pelvis

agents, our case report suggests infliximab can be effective in treatment of refractory sarcoidosis involving pelvic bone $[3,4]$.

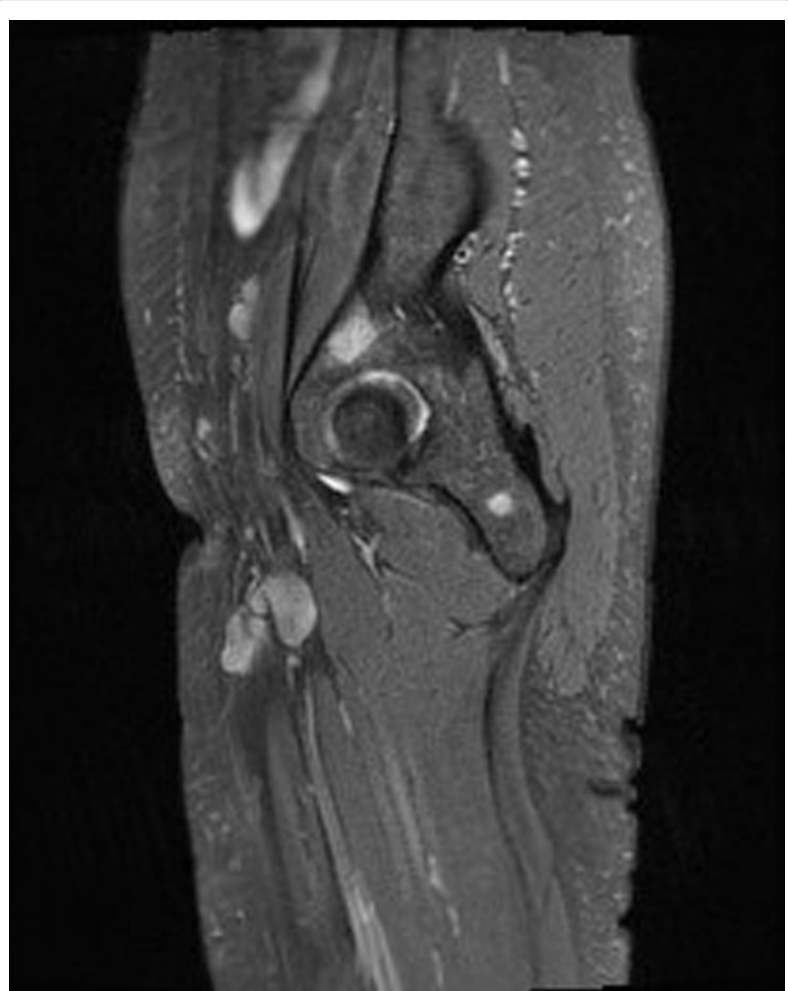

Figure 3 Lesion over Rt acetabulum

\section{Conclusion}

This is first case reported on successful use of anti-TNF in treatment of multisystem sarcoidosis involving pelvic bone. There is currently limited evidence for biological agents such as infliximab, a monoclonal anti-TNF $\alpha$ antibody in the treatment of multisystem sarcoidosis [1]. Our case supports the need for randomized controlled clinical trials of anti-TNF therapy in refractory systemic sarcoidosis.

Published: 14 February 2013

\section{References}

1. Croft AP, Situnayake D, Khair O, Giovanni G, Carruthers D, Sivaguru A, Gordon C:: Clin Rheumatol 2012, 31(6):1013-8, Epub 2012 Jan 17.

2. Bargagli $E$, Olivieri $C$, et al: Rare localizations of bone sarcoidosis, two case reports and review of the literature. Rheumatol Int 2011, 31(11):1503-6, Epub 2009 Dec 15.

3. Garg S, Garg K, Altaf M, Magaldi JA: Refractory vertebral sarcoidosis responding to infliximab. J Clin Rheumatol 2008, 14(4):238-40.

4. Hasni SA, Kunz D, Finzel K, Gruber : Osseous sarcoidosis treated with tumor necrosis factor-inhibitors: case report and review of the literature. Spine (Phila Pa 1976) 2010, 35(18):E904-7.

doi:10.1186/1471-2474-14-S1-A9

Cite this article as: Karjigi and Paul: Refractory multisystem sarcoidosis involving pelvic bone responding to infliximab. BMC Musculoskeletal Disorders 2013 14(Suppl 1):A9.

\section{Submit your next manuscript to BioMed Central and take full advantage of:}

- Convenient online submission

- Thorough peer review

- No space constraints or color figure charges

- Immediate publication on acceptance

- Inclusion in PubMed, CAS, Scopus and Google Scholar

- Research which is freely available for redistribution
Biomed Central 